Pak. j. sci. ind. res. Ser. B: biol. sci. 2016 59(2) 99-104

\title{
Antiplasmodial Activity of Methanolic Extract of Asparagus officinalis L. Stem on Plasmodium berghei Infected Mice
}

\author{
Joseph Bamidele Minaria*, Adewale. Agboola Odutuga ${ }^{\text {b }}$, Fisayo Abraham Bamisaye ${ }^{c}$ \\ and Leye Jonathan Babatolab \\ ${ }^{a}$ Department of Cell Biology and Genetics, University of Lagos, Lagos, Nigeria \\ ${ }^{b}$ Department of Biochemistry, Joseph Ayo Babalola University, Ikeji-Arakeji, Osun State, Nigeria

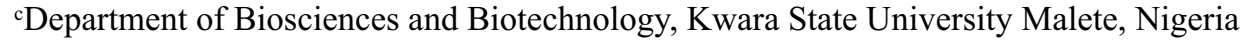

(received January 08, 2015; revised November 24, 2015; accepted December 12, 2015)

\begin{abstract}
This study aims at investigating the antiplasmodial activity of methanolic extract of Asparagus officinalis L. stem on Plasmodium berghei infected mice. To investigate this, the mice were infected with P.berghei to cause malaria. The mice were simultaneously given oral doses $(20,40$ and $60 \mathrm{mg} / \mathrm{kg}$ body weight) of methanolic extract of $A$. officinalis $\mathrm{L}$. stem. The phytochemical constituents of the extract revealed the presence of alkaloids, phenolics, cardiac glycosides, flavonoids, terpenoid and steroid. The extract administered to the infected mice significantly suppressed the parasite. The extract also significantly $(\mathrm{P}<0.05)$ reduced the activities of serum aspatate aminotransferase (AST), alkaline phosphate (ALP), alanine aminotransferase (ALT). White blood corpuscles (WBC), red blood corpuscles (RBC), hemoglobin (HGB), packed cell volume (PCV), platelets (PLT) and the mean corpuscular hemoglobin concentration (MCHC) showed significant $(\mathrm{P}<0.05)$ increase after the administration of the extract while mean corpuscular volume $(\mathrm{MCV})$ and the mean corpuscular hemoglobin $(\mathrm{MCH})$ showed significant $(\mathrm{P}<0.05)$ reduction. Present findings suggests that the plant extract contains phytochemicals that have antiplasmodial and hepatoprotective properties.
\end{abstract}

Keywords: antiplasmodial activity, Asparagus officinalis, Plasmodium berghei, phytochemicals

\section{Introduction}

Malaria is one of the world's most devastating human infections. A mosquito borne infectious disease that attacks human and other animals caused by a parasite known as plasmodium. It is spread through the bite of an infected female mosquito (anopheles) which transmit malaria via its saliva into the human system, thus affecting the liver where they mature and reproduce. Malaria has certain symptoms such as headache and fever, the present global situation indicates a recent resurgence in the severity of the disease and that malaria could still be described as one of the most important communicable diseases, with an annual incidence of 300-500 million clinically manifest cases and a death toll of 1-2 million people (Martin et al., 2004). Malaria is on the increase in Nigeria and other Sub-Saharan areas of Africa, carrying along with it high morbidity and mortality rates.

Four identified species of this parasite exist, which cause different types of human malaria, namely; Plasmodium vivax, Plasmodium falciparum, *Author for correspondence; E-mail:baminjoe@yahoo.co.uk
Plasmodium ovale and Plasmodium malariae. All of which are transmitted by the female Anopheles mosquito (Hardman and Limbird 2001) through the bite of infected female Anopheles mosquitoes as well as sharing of contaminated needles, blood transfusion, organ transplantation and those that are congenitally acquired (Guerra et al., 2008). The Plasmodium knowlesi which naturally infects macque monkeys is the cause of zoonotic malaria in humans (Hobbs and Duffy, 2011). P. falciparum causes the majority of malaria cases worldwide especially in Africa (Nchinda,1998). But it is also becoming more difficult to treat malaria due to the increasing drug resistance. Over time malaria has developed new strains causing resistance to anti malarial drugs which has been a major setback in the fight against malaria and its attendant complications (Wongsrichanalai et al., 2002). In order to meet up with this challenge, there is urgent need to double the herbal chemotherapeutic research efforts aimed at tackling the resistance of malaria to antimalarial drugs.

Plants have been the basic source of sophisticated traditional medicine system for thousands of years and 
were instrumental to early pharmaceutical drug discovery and industry (Elujoba et al., 2005). Various plants contain medicinal properties such as Morinda lucida (oruwo), Enantia chlorantha (awopa), Asparagus africanus, Azadirachta indica (dongoyaro). The leaf extract of Erythrina indica and root extract of Asparagus racemosus have the potential to be used as an ideal ecofriendly approach for the control of mosquitoes (Govindarajan and Sivakumar, 2015). The methanolic extracts of Albizia coriaria and Aspergillus racemosa had been reported to demonstrate moderate antiplasmodial activity (Kigondu et al., 2009). Asparagus officinalis $\mathrm{L}$. is a spring vegetable and a flowering perennial plant. It has been known to serve as a very good source of vitamin $\mathrm{C}$ and help to protect small blood vessels from rupturing. Whereas several works have been done on the medicinal properties of $A$. officinalis $\mathrm{L}$., the information as regards its antimalarial properties is not readily available.

This study was therefore, carried out to investigate the antimalarial properties of the methanolic extract of A. officinalis L. stem on P. berghei infected mice.

\section{Materials and Methods}

Experimental animals. For this study 20 mice were obtained from the Department of Pharmacology, University of Lagos, Akoka, Nigeria. The animals (20 to $25 \mathrm{~g}$ ) were of the same sexes. They were fed with standard animal pellets and tap water (ad libitum). This research was carried out in the Department of Cell Biology and Genetics, University of Lagos, Akoka, Lagos State, according to the rules in Nigeria governing the use of laboratory animals (Revised Helsinki Declaration, 2008) as acceptable internationally.

Chemicals and agents. Picric acid solution $(1 \%)$ is a product of B. Merck Darmastacli Laboratory. The concentrated sulphuric acid (10\%) was obtained from BDH Chemicals Limited, Poole, England and all other laboratory reagents were of analytical grade.

Plant materials and extraction: The stem of $A$. officinalis L. were bought at Shoprite shopping mall, Ikeja, Lagos and were identified at the herbarium section Department of Botany of the University of Lagos. Asparagus officinalis stem were chopped into smaller pieces and then sun dried for 2 weeks. It was milled to powered form using a grinding machine. The crude powder $(73 \mathrm{~g}$ each) was extracted using $70 \%$ methanol. The powder was soaked for 1 week and thereafter filtered using
Whatman filter paper. The filtrate was then evaporated to dryness by heating in a oven at $65^{\circ} \mathrm{C}$.

Phytochemical screening. Phytochemical analysis of the methanolic extracts of the plan species was carried out following the methods decribed by Odebiyi and Sofowora (1978).

Parasite. A dihydroaertemisin-sensitive strain of $P$. berghei was obtained from the Department of Pharmacology, Lagos University Teaching Hospital, University of Lagos, Lagos State, Nigeria.

Inoculation and confirmation of malaria parasite (Parasitaemia). The mice were screened for malaria parasite in their blood and only animals that were free from malaria parasites were selected for this study. The selected animals were taken to the animal house of the Department of Cell Biology and Genetics, University of Lagos, Akoka, Lagos State where they were allowed to acclimatize in the laboratory for two weeks before the commencement of the experiment. P. berghei of $0.1 \mathrm{~mL}$ in $5 \mathrm{~mL}$ from a donor mice (infected) was mixed with $5.0 \mathrm{~mL}$ of PBS ( phosphate buffer saline) then each mice was infected through the intra-peritioneal route at the commencement of the experiment (day1).The mice were inoculated with malaria parasite and allowed to incubate for $72 \mathrm{~h}$ (3days) after which thin blood film was prepared from tail snip, and stained using Giemsa stain and the parasitaemia confirmed by viewing using x100 objective of light microscope. All the inoculated mice were parasitaemia confirmed after 4 days.

Malarial parasite density determination. This was done by parasitaemia count and expressed as percentage parasitaemia. Determination and record of percentage parasitaemia was commenced on the first day of treatment which is day 3 of the experiment. The treatment was done for 5 days which ended on day $7^{\text {th }}$ of the experiment.

Screening for antimalarial activity of $\boldsymbol{A}$. officinalis L. About 10-12 weeks old 20 male mice, average weight of about $22 \mathrm{~g}$ were used. They were grouped into five groups with four mice per group. Group A (Control) consisted of uninfected mice treated with $0.2 \mathrm{~mL}$ oral distilled water for five days. Group B consisted of infected mice which were not treated. The mice in groups $\mathrm{C}$ to $\mathrm{E}$ were infected mice and treated with the extracts.

Determination of haematology parameters. RBC, WBC, PCV, HGB, MCHC, MCB, MCV and PLT were determined according to the methods described by Adewuyi and Olatunji (1995). 
Enzyme assay. The assay method employed for the assay of alkaline phosphatase (ALP) was based on the procedure described by Roy (1970) while the activities of ALT, AST were assayed basically by the method of Reitman and Frankel (1957)

Statistical analysis. This was carried out by one way analysis of variance and Duncan Multiple Range test. $\mathrm{P}<0.05$ was considered significant.

\section{Results and Discussion}

Table 1 shows the phytochemical screening of the methanolic extract of Asparagus officinalis stem. This revealed the presence of phenolics, alkaloids, cardiac glycosides, flavonoids, terpenoid, and steroid. However, the screening showed absence of constituents such as tannins, phlobatannin and reducing sugar.

Figure 1 shows the effect of methanolic extract administaered at different dose levels on the percentage parasitaemia level in $P$. berghei infected mice. It was observed that the control A showed no level of parasitaemia during the experiment which commenced on day 3 and ended 5 days later (day 8 of experiment), while the untreated group revealed significant increase in level of the parasite throughout the experiment. The methanolic extract of $A$. officinalis L. caused a slight increase in parasitaemia level for (mice administered $20 \mathrm{mg} / \mathrm{kg}$ of Asparagus for 5 days) MAA which eventually dropped in day $7^{\text {th }}$ of the experiment. There was a significant decrease in the parasite level for (Mice administered $40 \mathrm{mg} / \mathrm{kg}$ of Asparagus extract for 5 days), MAB and (mice administered $60 \mathrm{~mL} / \mathrm{kg}$ of Asparagus for 5 days), MAC in which the parasitaemia level decreased as the days of the experiment passed but MAC was more effective than MAB.

Table 1. Phytochemical screening of methanolic extracts of Asparagus officinalis L. stem

\begin{tabular}{ll}
\hline \hline $\begin{array}{l}\text { Phytochemical } \\
\text { component }\end{array}$ & $\begin{array}{l}\text { Methanolic } \\
\text { extract }\end{array}$ \\
\hline Alkaloids & Present \\
Tannins & Absent \\
Phenolics & Present \\
Cardiac glycosides & Present \\
Phlobatanins & Absent \\
Flavonoids & Present \\
Terpenoid & Present \\
Steroid & Present \\
Reducing sugar & Absent \\
\hline \hline
\end{tabular}

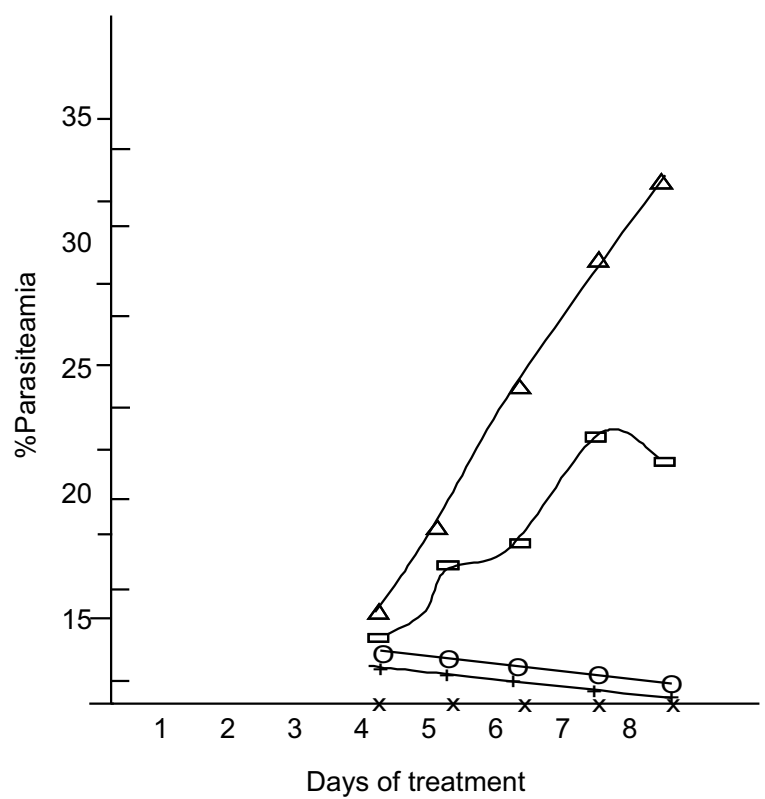

$\triangle-$ Untreated $\square 20 \mathrm{mg} / \mathrm{kg} \quad \ominus 40 \mathrm{mg} / \mathrm{kg}+60 \mathrm{mg} / \mathrm{kg}$

Fig. 1. Effects of administration of methanolic extract of Asparagus officinalis L. stem on parasitaemia level in plasmodium berghei infected mice.

The methanolic extract of $A$. officinalis L. significantly $(\mathrm{P}<0.05)$ reduced AST level of the treated groups when compared to the control group in Table 2 .

Effects of administration of methanolic extract of $A$. officinalis L. stem on specific activity of ALT in the serum of mice is shown in Table 3. The activity of ALT in the serum of the mice showed that there was significant $(p<0.05)$ decrease in the level of ALT in the treatment groups when compared to the control groups observed inTable 3. Also, the activities of ALP in the serum of the treated mice were significantly $(\mathrm{P}<0.05)$ decreased when compared with the control group (Table 4).

Table 2. Effects of administration of methanolic extract of Asparagus officinalis L. stem on specific activity of aspartate aminotransferase (AST) in the serum of mice

\begin{tabular}{ll}
\hline \hline Treatment & $\begin{array}{l}\text { Aspartate aminotransferase } \\
\text { activity }(\mathrm{nm} / \mathrm{min} / \mathrm{mg} / \text { protein })\end{array}$ \\
\hline Control A & $251.85 \pm 0.191 \mathrm{a}$ \\
Control B & $272.50 \pm 1.061 \mathrm{~b}$ \\
MAA & $201.85 \pm 0.310 \mathrm{c}$ \\
MAB & $208.27 \pm 0.403 \mathrm{~d}$ \\
MAC & $203.02 \pm 1.034 \mathrm{~d}$ \\
\hline
\end{tabular}

Values are means of 4 replicates \pm S.D, values with different superscript are significantly different $(\mathrm{P}<0.05)$. 
Table 3. Effects of administration of methanolic extract of Asparagus officinalis L. stem on specific activity of alanine aminotransferase (ALT) in the serum of mice

\begin{tabular}{ll}
\hline \hline Treatment & $\begin{array}{l}\text { Alanine aminotransferase } \\
\text { activity }(\mathrm{nm} / \mathrm{min} / \mathrm{mg} / \text { protein })\end{array}$ \\
\hline Control A & $70.67 \pm 0.236 \mathrm{a}$ \\
Control B & $77.97 \pm 0.359 \mathrm{~b}$ \\
MAA & $24.51 \pm 0.431 \mathrm{c}$ \\
MAB & $46.87 \pm 0.298 \mathrm{~d}$ \\
MAC & $38.57 \pm 0.478 \mathrm{~d}$ \\
\hline \hline
\end{tabular}

Values are means of 4 replicates \pm S.D, values with different superscript are significantly different $(\mathrm{P}<0.05)$.

Table 4. Effects of administration of methanolic extract of asparagus officinalis $\mathrm{L}$. stem on specific activity of alkaline phosphate (ALP) in the serum of mice

\begin{tabular}{ll}
\hline \hline Treatment & $\begin{array}{l}\text { Alkalinephosphate activity } \\
(\mathrm{nm} / \mathrm{min} / \mathrm{mg} / \text { protein })\end{array}$ \\
\hline Control A & $152.42 \pm 1.093 \mathrm{a}$ \\
Control B & $98.20 \pm 0.535 \mathrm{~b}$ \\
MAA & $134.62 \pm 0.386 \mathrm{c}$ \\
MAB & $63.85 \pm 0.264 \mathrm{~d}$ \\
MAC & $87.75 \pm 0.208 \mathrm{e}$ \\
\hline \hline
\end{tabular}

Values are means of 4 replicates \pm S.D, values with different superscript are significantly different $(\mathrm{P}<0.05)$.

Table 5 shows the effects of administration of methanolic extracts of A. officinalis $\mathrm{L}$. stem on some haematological parameters in the serum of mice. The WBC, RBC, the $\mathrm{HGB}$, and $\mathrm{PCV}$ all showed significant $(\mathrm{P}<0.05)$ increase when the treatment groups were compared to the control groups except for the case of MAA (mice administered $20 \mathrm{mg} / \mathrm{kg}$ of Asparagus) observed in the HGB and PCV test. There was a significant $(\mathrm{P}<0.05)$ increase in the PLT and the MCHC when the treatment groups were compared to the control groups, except for the case of MAB observed in MCHC, for the MCV and the MCH there was a significant $(\mathrm{p}<0.05)$ decrease or reduction when the treatment groups were compared to the control groups, except for the case of MAC observed in $\mathrm{MCH}$.

The results obtained from the phytochemical screening of the extract in Table 1 agrees with those reported by Ogundare and Onifade (2009) and Patience and Godwin (2010) which stated that phenolics, alkaloids, cardiac glycosides, flavonoids, terpenoids, and steroids are present in the methanolic extract of A. officinalis $\mathrm{L}$.

The significant reduction observed from Fig. 1 in the groups administered with the methanolic extract of $A$. officinalis L. suggests the antiplasmodial property of the extract which is in agreement with the findings of Naghibi et al. (2013). The extracts of A. officinalis L. contain different secondary metabolites that have antiplasmodial activity in some plants (Abdulelah and Zainal-Abidin, 2007). Tannins (Asres et al., 2001), alkaloids (Saxena et al., 2003), and phenols (Hilou et al., 2006) have also been reported to be responsible for antiplasmodial activity of some plants. The effects of the extract on parasitaemia level in this study are similar to the ones reported by previous studies such as on Asparagus africanus (Dikasso et al., 2006), Amarantus spinosus (Hilou et al., 2006) and Withania somnifera (Dikasso et al., 2006). The antiplasmodial properties revealed in this study might be attributed to the various phytoconstituents of the extract. Thus the methanolic extracts of $A$. officinalis $\mathrm{L}$. stem has antiplasmodial properties in mice infected with $P$. berghei especially at $60 \mathrm{mg} / \mathrm{kg}$ of the extract. Although rodents do not produce exactly the signs and symptoms observed in the human plasmodial infection (Pedroni et al., 2006) they however, have been reported to produce disease features similar to those of human plasmodial infection with P. berghei (Alli et al., 2011)

The toxicological effect of methanolic extract of $A$. officinalis $\mathrm{L}$. stem on infected mice were evaluated. The significant decrease $(\mathrm{P}<0.05)$ in activities of serum ALP (Tables 4) in the group treated with the extracts

Table 5: Effects of administration of methanolic extracts of Asparagus officinalis L. stem on some haematological parameters in the serum of mice

\begin{tabular}{lllllllll}
\hline \hline Treatment & WBC(X109/l) & RBC & HGB $(\mathrm{g} / \mathrm{dl})$ & PCV(\%) & PLT & MCV(fl) & MCH & MCHC \\
\hline Control A & $4.95 \pm 0.057 \mathrm{a}$ & $7.78 \pm 0.189 \mathrm{a}$ & $12.12 \pm 0.050 \mathrm{a}$ & $41.17 \pm 0.512 \mathrm{a}$ & $763.50 \pm 5.066 \mathrm{a}$ & $52.22 \pm 0.442 \mathrm{a}$ & $15.05 \pm 0.129 \mathrm{a}$ & $29.40 \pm 0.454 \mathrm{a}$ \\
Control B & $5.30 \pm 0.258 \mathrm{~b}$ & $7.85 \pm 0.200 \mathrm{~b}$ & $12.15 \pm 0.057 \mathrm{~b}$ & $41.50 \pm 0.432 \mathrm{~b}$ & $633.00 \pm 4.966 \mathrm{~b}$ & $52.07 \pm 0.826 \mathrm{~b}$ & $14.95 \pm 0.208 \mathrm{~b}$ & $28.57 \pm 0.434 \mathrm{~b}$ \\
MAA & $5.15 \pm 0.191 \mathrm{c}$ & $8.03 \pm 0.039 \mathrm{c}$ & $12.12 \pm 0.050 \mathrm{a}$ & $40.02 \pm 0.170 \mathrm{c}$ & $735.50 \pm 5.196 \mathrm{c}$ & $49.80 \pm 0.182 \mathrm{c}$ & $14.72 \pm 0.170 \mathrm{~b}$ & $30.12 \pm 0.263 \mathrm{~b}$ \\
MAB & $5.77 \pm 0.095 \mathrm{~d}$ & $8.68 \pm 0.111 \mathrm{~d}$ & $12.95 \pm 0.129 \mathrm{~d}$ & $43.32 \pm 0.359 \mathrm{c}$ & $869.25 \pm 9.464 \mathrm{c}$ & $49.17 \pm 0.450 \mathrm{c}$ & $14.70 \pm 0.182 \mathrm{~b}$ & $29.25 \pm 0.479 \mathrm{a}$ \\
MAC & $5.10 \pm 0.115 \mathrm{~d}$ & $8.95 \pm 0.084 \mathrm{~d}$ & $13.35 \pm 0.369 \mathrm{e}$ & $44.32 \pm 0.442 \mathrm{c}$ & $711.25 \pm 2.629 \mathrm{c}$ & $49.10 \pm 0.535 \mathrm{c}$ & $15.10 \pm 0.216 \mathrm{a}$ & $30.47 \pm 0.403 \mathrm{~b}$ \\
\hline \hline
\end{tabular}

Values are means of 4 replicates \pm S.D., values with different superscript are significantly different $(\mathrm{P}<0.05$. 
when compared to the control suggests that there may be hindrance for the adequate transportation of the required ions on the molecules across the plasma membrane (Akanji et al., 1993). This may lead to less availability of the phosphate groups for the phosphorylation of ethanolamine and choline needed for the synthesis of major phospholipids. AST and ALT reduction suggests that the extract might not be hepatotoxic or nephrotoxic since there was no significant leakage of the enzymes from the liver or the kidney of the treatment group of the mice.

Anaemia was significantly associated with malaria in this study due to the significant $(\mathrm{P}<0.05)$ increase in $\mathrm{RBC}$ and $\mathrm{Hb}$ count of all the groups infected (both treated and untreated) with the parasite. The MCHC which was significantly reduced $(\mathrm{P}<0.05)$ suggests the reduction in oxygen carrying capacity for all the groups infected (both treated and untreated). The MCHC is an index of haemoglobin concentration per red cell indicating the oxygen carrying capacity of each red cell. The inverse relationship between $\mathrm{MCHC}$ and parasitaemia is expected knowing that anemia is occurring due to the significant increase $(\mathrm{P}<0.05)$ in RBC count (Uneke, 2008). Probably the increase in $\mathrm{MCHC}$ is compensatory for the presence of the parasite at the red cell level. However, the significant $(\mathrm{P}<0.05)$ increase in PCV indicates a boosted immune system.

It could be concluded that $A$. officinalis L. stem contains metabolites which posseses antiplasmodial properties with less hepatotoxic effect but capable of boosting the immune system.

\section{References}

Abdulelah, H. A. A., Zainal-Abidin, B. A. H. 2007. In vivo antimalarial tests of Nigella sativa (black seed) different extracts. American Journal of Pharmacology and Toxicology, 2:46-50.

Adewuyi, J.O., Olatunji, P.O. 1995. Manual of Practical Haematology for the MBBS Course. University of Ilorin, Ilorin, Nigeria.

Akanji, M.A., Olagoke, O.A., Oloyede, O.B. 1993. Effect of chronic consumption of metabisulphite on the integrity of the rat kidney cellular system. Toxicology, 81: 173-179.

Alli, L. A., Adesokan, A.A., Salawu, O.A., Akanji, M.A., Tijani, A.Y. 2011. Antiplasmodial activity of aqueous root extract of Acacia nilotica. African Journal of Biochemical Research, 5: 214-219.

Asres, K., Bucar, F., Knauder, E., Yardley, V., Kendrick,
H., Croft, S. L. 2001. In vitro antiprotozoal activity of extract and compounds of stem bark of Combretum molle. Phytotherapy Research, 15: 613-617.

Dikasso, D., Makonnen, E., Debella, A., Abebe, D., Urga, K., Makonnen, W., Melaku, D., Assefa, A., Makonnen, Y. 2006. In vivo antimalarial activity of hydroalcoholic extracts from Asparagus africanus Lam. in mice infected with Plasmodium berghei. Ethiopian Journal of Health Development, 20: 112-118.

Elujoba, A.A., Odeleye, O.M., Ogunyemi, C.M. 2005. Traditional medicine development for medical and dental primary health care delivery systems in Africa. African Journal of Traditional, Complementary and Alternative Medicine, 2: 46-61.

Govindarajan, M., Sivakumar, R. 2015. Laboratory eveluation of Indian medicial plants as repellents against malaria, dengue, and filariasis vector mosquitoes. Parasitology Research, 114:601-612.

Guerra, C.A., Gikandi, P.W., Tatem, A.J., Noor, A. M., Smith, L., Hay, S.I., Snow, R.W. 2008. The limits and intensity of plasmodium falciparum transmission: Implications for malaria control and elimination worldwide. PLOS Medical, 5: 38.

Hardman, J.G., Limbird, L.E. 2001. Drugs used in the chemotherapy of malaria. In: The Goodman and Gilman's Pharmacological Bases of Therapeutics, L. Brunton, J. Lazoand, K. Parker (eds.), pp.1069$1100,10^{\text {th }}$ edition, Mc Graw- Hill, New York, NY, USA.

Hilou, A., Nacoulma, O.G., Guiguemde, T.R. 2006. In vivo antimalarial activities of extracts from Amaranthus spinosus L. and Boerhaavia erecta L. in mice. Journal of Ethnopharmacology, 103: 236240.

Hobbs, C., Duffy, P. 2011. Drugs for malaria: something old, something new, something borrowed. F1000 Biology Reports, 3: 1-9.

Kigondu, E.V., Rukunga, G.M., Keriko, J.M., Tonui, W.K., Gathirwa, J.W., Kirira, P.G., Irungu, B., Ingonga, J.M., Ndiege, I.O. 2009. Anti-parasitic activity and cytotoxicity of selected medicinal plants from Kenya. Journal of Ethnopharmacology, 123: 504-509.

Martin, S.A., Bygbjerg, I. B.C., Joil, G.B. 2004. Are multilateral malaria research and control programs the most successful? Lessons from the past 100 years in Africa. The American Journal of Tropical Medicine and Hygiene. 2: 268-278. 
Naghibi, F., Esmaeili, S., Abdullah, N.R., Neteghpour, M., Taghvai, M., Kamkar, S., Mosaddegh, M. 2013. In vitro and in vivo antimalarial evaluations of Myrtle extract, a plant traditionally used for treatment of parasitic disorder. BioMed Research International, 2013: 316185-316189.

Nchinda, T.C. 1998. Malaria: are emerging disease in Africa. Emerging Infectious Diseases, 4:398-403.

Odebiyi, A., Sofowora, A. E. 1978. Phytochemical screening of Nigerian medicinal plants, Part III. Liyodia, 41: 234-246.

Ogundare, A. O., Onifade, A.K. 2009. The antimicrobial activity of Morinda lucida leaf extract on Escherichia coli. Journal of Medicinal Plants Research, 3: 319-323.

Patience, O.A., Godwin, E.U. 2010. Antibacterial activity of aqueous and ethanolic crude extracts of the roots barks of Alstonia boonei and prelipminary phytochemical test of Morinda lucida. Journal of Medicinal Plants Research, 4: 644-648.

Pedroni, H.C., Bettoni, C.C., Spalding, S.M., Costa, T.D. 2006. Plasmodium berghei: Development of an irreversible experimental malaria model in Wistar rats. Experimental Parasitology, 113: 193-196.
Reitman, S., Frankel, S. 1957. A colorimatric method for determination of serum glutamate oxaloacetate and glutamic pyruvate transaminase. American Journal of Clinical Pathology, 28:56-63.

Roy, A.V. 1970. Rapid method for determination of alkaline phosphatase activity in human serum with thymolphthalein monophosphate. Clinical Chemistry, 16: 431 .

Rukunga, G., Simons, A. J. 2006. The Potential of Plants as a Source of Antimalarial Agents-A Review. 72 pp., A Review of Africa Herbal Antimalarial Meeting. PlantaPhile Publications, Berlin, Germany. Saxena, S., Pant, N., Jain, D.C., Bhakuni, R.S. 2003. Antimalarial agents from plant sources. Current Science, 85: 1314-1329.

Uneke, C. J. 2008. Impact of placental Plasmodium falciparum malaria on pregnancy and perinatal outcome in sub-Sahara Africa: Part III: Placental malaria, maternal health and public health. Yale Journal of Biology and Medicine, 81: 1-7.

Wongsrichanalai, C., Pickard, A.L., Wernsdofer, W.H., Meshnick, S.R. 2002. Epidemiology of drug resistant malaria. The Lancet Infectious Diseases, 2: 209-218. 